\title{
APICAL ROOT RESORPTION IN TEETH AFTER THE TREATMENT OF CLASS II MALOCCLUSION WITH FORSUS FRD AND FIXED TECHNIQUE
}

\section{SINIF 2 MALOKLÜZYONLARIN FORSUS FRD VE SABİT TEKNİK İLE TEDAVİSİ SONRASINDA DİŞLERDE GELİŞEN APİKAL KÖK REZORPSIYYONU}

Doç.Dr. Belma IŞIK ASLAN*

Prof. Dr. Zühre AKARSLAN** Arş. Gör. Özge KARADAĞ ${ }^{* * *}$

\author{
Makale Kodu/Article code: 4521 \\ Makale Gönderilme tarihi: 21.07.2020 \\ Kabul Tarihi: 03.03.2021
}

DOI : $10.17567 /$ ataunidfd. 890346
Belma Işık Aslan:_ORCID ID: 0000-0002-9751-570x

Zühre Akarslan: ORCID ID: 0000-0001-9237-412x

Özge Karadağ: ORCID ID: 0000-0002-2650-1458

\section{ABSTRACT}

Aim: To assess apical root resorption (ARR) after Class II malocclusion treatment with the Forsus FRD and fixed technique and to identify the possible risk factors retrospectively.

Material and Methods: Seventy-three Class II patients (52 females, 21 males; mean age 14.26 \pm 1.28 years) treated with Forsus FRD and fixed technique in the department of Orthodontics were included in this study. The crown and root lengths of 1368 teeth were measured from the panoramic radiographs taken at the beginning and the end of the treatment from these patients. ARR was calculated as the root-crown ratio (RCR) and relative changes of RCR (rRCR). Apical displacement of the incisors was assessed by the superimposition of the lateral cephalograms taken at the beginning and the end of the treatment. Besides, the effect of age, gender, treatment period, tooth type, and apical displacement on ARR was evaluated. Data were statistically analyzed.

Results: ARR was detected in $66(90.41 \%)$ patients and $228(16.67 \%)$ teeth. ARR was mild $(90 \leq r R C R<100 \%)$ in 181 $(13.23 \%)$ teeth, moderate $(80 \leq r R C R<90 \%)$ in $30(2.19 \%)$ teeth, and severe (rRCR $\leq 80)$ in $17(1.24 \%)$ teeth. Severe ARR occurred mostly in the upper central and lateral teeth. A significant negative correlation was found between rRCR and, age and tooth type $(p<0.05)$.

Conclusion: Orthodontic treatment of Class II malocclusion with Forsus FRD and fixed technique could lead to mild ARR in the majority of the patients. ARR is mostly seen in the incisor teeth and increases with advanced age.

Key Words: Root resorption, orthodontic appliances, malocclusion, Angle Class II

\section{öz}

Amaç: Forsus FRD ve sabit teknik ile tedavi edilen Sınıf 2 maloklüzyonlarda, tedavi sonrası apikal kök rezorpsiyonunun (AKR) incelenmesi ve olası risk faktörlerinin retrospektif olarak tanımlanmasıdır.

Gereç ve Yöntem: Bu çalışmaya Ortodonti Anabilim Dalı'nda Forsus FRD ve sabit teknik ile tedavi edilmiş olan Sınıf 2 maloklüzyona sahip 73 hasta (52 kadın; 21 erkek; yaş ortalaması 14.26士1.28) dahil edildi. Bu hastaların, tedavi öncesinde ve tedavi sonrasında çekilen panoramik radyograflarından 1368 dişin, kron ve kök uzunlukları ölçüldü. AKR, kök-kron oranı (RCR) ve RCR'nin bağıl değişkenleri (rRCR) olarak hesaplandı. Tedavi öncesi ve tedavi sonrasında alınan lateral sefalogramların çakıştırılması ile kesici dişlerin apikal yöndeki yer değiştirmesi değerlendirildi. Bunlara ilave olarak, yaş, cinsiyet, tedavi süresi, diş tipi ve apikal yer değiştirmenin AKR'ye etkisi incelendi. Veriler istatistiksel olarak analiz edildi.

Bulgular: Altmış altı hastada (\%90.41) ve 228 dişte (\%16.67) AKR saptandı. AKR, $181(\% 13.23)$ dişte hafif $(90 \leq$ rRCR $<100 \%)$, $30(\% 2.19)$ dişte orta $(80 \leq$ rRCR $<90 \%)$ ve $17(\% 1.24)$ dişte şiddetli $(r R C R \leq 80)$ düzeydeydi. Şiddetli AKR en fazla üst santral ve lateral dişlerde görüldü. rRCR'nin yaş ve diş tipi ile anlamlı düzeyde negatif yönde ilişki gösterdiği belirlendi $(p<0.05)$.

Sonuç: Sınıf 2 maloklüzyonların Forsus FRD ve sabit tedavi ile yapılan ortodontik tedavisi, birçok hastada hafif düzeyde AKR'ye neden olabilmektedir. AKR, çoğunlukla kesici dişlerde görülmektedir ve yaşın ilerlemesiyle birlikte artmaktadır.

Anahtar Kelimeler: Kök rezorpsiyonu, ortodontik gereçler, maloklüzyon, Angle Sınıf 2

* Gazi University, Faculty of Dentistry, Department of Orthodontics, Ankara.

** Gazi University, Faculty of Dentistry, Department of Oral and Maxillofacial Radiology, Ankara.

${ }^{* * *}$ Hacettepe University, Faculty of Science, Department of Statistics, Ankara.

Kaynakça Bilgisi: Işık Aslan B, Akarslan Z, Karadağ Ö. Sınıf 2 maloklüzyonların forsus frd ve sabit teknik ile tedavisi sonrasında dişlerde gelişen apikal kök rezorpsiyonu. Atatürk Üniv Diş Hek Fak Derg 2021; 31: 188-95.

Citation Information: Isık Aslan B, Akarslan Z, Karadag O. Apical root resorption in teeth after the treatment of class ii malocclusion with forsus frd and fixed technique. J Dent Fac Atatürk Uni 2021; 31: 188-95. 


\section{INTRODUCTION}

Apical root resorption (ARR) is an undesirable, irreversible consequence of orthodontic treatment. ${ }^{1-3}$ Studies have reported a high incidence, up to $91 \%$ of teeth. ${ }^{4}$ Mild to moderate resorption has been usually observed in radiographic researches $(<2.5 \mathrm{~mm})^{5,6}$ with an incidence of $6 \%$ to $13 \%$ in treated teeth. ${ }^{7}$ Severe resorption (exceeding one-third of the initial root length or $4 \mathrm{~mm}$ ) has been detected of $1-5 \%$ in different types of teeth.

The etiology of ARR is multifactorial. Risk factors related to orthodontic treatment have been reported as the magnitude of the force, ${ }^{8}$ direction and amount of apical displacement, ${ }^{9}$ appliance type, ${ }^{9}$ cortical plate approximation, ${ }^{10,11}$ severity of malocclusion, 8,12 extraction therapy, and treatment duration. ${ }^{13}$ Individual biologic variability and genetic factors have been reported to increase the susceptibility to ARR. 8,14

Various types of tooth movements such as intrusion, torque, and tipping concentrate forces near the apex of the root thus, they have been claimed to promote ARR. ${ }^{12,15}$ The difference in the orientation of the periodontal fibers and cement resistance covering the apical tip are predisposing factors of resorption near the apex. ${ }^{16}$

It is crucial to specify the factors related to different orthodontic modalities to reduce the rate of ARR. Class II or Class III orthodontic therapies may be risky for ARR than Class I orthodontic therapies since the severity of malocclusion is greater. ${ }^{10}$ In a systematic review, it has been demonstrated that mild to moderate resorption of the incisors was common following non-surgical Class II Div1 treatment mechanics. ${ }^{17}$

Fixed functional appliances lead to severe complex forces during orthodontic treatment. ${ }^{18}$ Forsus Fatigue Resistant Device (FRD) is a semi-rigid fixed functional appliance used in the treatment of Class II cases. Retrusion of upper incisors, protrusion of lower incisors, mesialization of lower molars, intrusive and distalization of upper molars, have been reported with this appliance. ${ }^{19}$ Therefore, we aimed to evaluate ARR during Class II treatment with Forsus FRD and fullfixed appliances with panoramic radiographs and identify possible risk factors.

\section{MATERIAL AND METHODS}

Ethical approval for this retrospective research was granted by Gazi University Ethics Committee (Approval number: 2018-227). The sample was retrieved from the archive of the orthodontics department of Gazi University and comprised 73 patients (52 females and 21 males) who were treated with Forsus FRD (3M Unitek Corp, Monrovia, California) and full-fixed appliances (Roth appliances; 0.018 -inch slots). The ages of the patients ranged from 12 to16 years (mean \pm standard deviation= 14.26 \pm 1.28 ). All patients had at least a half Class II molar relationship at the beginning of the treatment. Forty-one cases had an Angle Class II Div1 and 32 had a Div 2 malocclusion. In all cases, the maxillary end of the Forsus device was inserted through the headgear tube of maxillary first molars and the rods of this appliance were placed onto the mandibular archwire, distal to the canine brackets. The fixed appliance therapy was performed under almost essentially standardized conditions. The average Forsus FRD and total treatment durations were $6.47 \pm 2.24$ and 29.34 \pm 9.65 months respectively.

Patients, requiring treatment with other orthodontic systems or temporary skeletal anchorage devices, having crowding more than $3 \mathrm{~mm}$, extracted or missing teeth, history of dental trauma, severely dilacerated roots or endodontic treatment, and radiographs with insufficient quality were excluded from the study. The panoramic and cephalometric radiographs were taken with an Orthopos XG digital Xray unit (Sirona, Dental $\mathrm{GmbH}$, Salzburg, Austria) by an experienced technician with standard positioning according to the manufacturer's recommendation. The panoramic images were obtained at $66 \mathrm{kVp}, 8 \mathrm{~mA}$ with $14.1 \mathrm{sec} X$-ray exposure time. The cephalometric images were taken at $73 \mathrm{kVp}, 15 \mathrm{~mA}$ with $14.9 \mathrm{sec} X-$ ray exposure time. The system works with a program named Metaaktar (Metasoft, Eskişehir, Türkiye). All images were viewed on a monitor (Philips, Lu Chu, Hsiang, Taiwan) of a computer having 1920×1080 pixels resolution (256 Bit, Hewlett Packard NB769AA graphics card, NVIDIA Quadro FX 380 GDDR3, Spring TX, United States) and printed with a special medical dry laser printer (Fuji Film, Dry Pix 2000; Fujifilm Corporation, Tokyo, Japan). All of the panoramic and cephalometric radiographs were printed in the same manner and dimensions. This procedure provided standardization of the radiographs. 
ARR was assessed from the panoramic images since they are routinely taken during orthodontic treatment. Incisors, canines, and second premolars in both arches; also, first premolars and molars in the mandibular arch were evaluated. In total, 1460 teeth were present. Out of these, 92 teeth were assessed as un-measurable due to un-detectable root apexes or enamel-dentine junction, periapical lesions, severely dilacerated root, endodontic treatment, or root resorption at the beginning of the study. Thus, the final sample consisted of 1368 teeth.

ARR was evaluated as the root crown ratio (RCR) and relative changes of RCR (rRCR). This method was also preferred in previous studies. ${ }^{20-22}$ Crown-root length ratio remains stable hence, this method eliminates magnification and projection errors on panoramic radiographs. The crown length was measured as the linear distance between the incisal edge and cemento-enamel junction, and the root length was measured from the root apex to the cemento-enamel junction on the long axis of the teeth. rRCR was calculated for each tooth according to the formula given in Figure 1. ${ }^{21}$

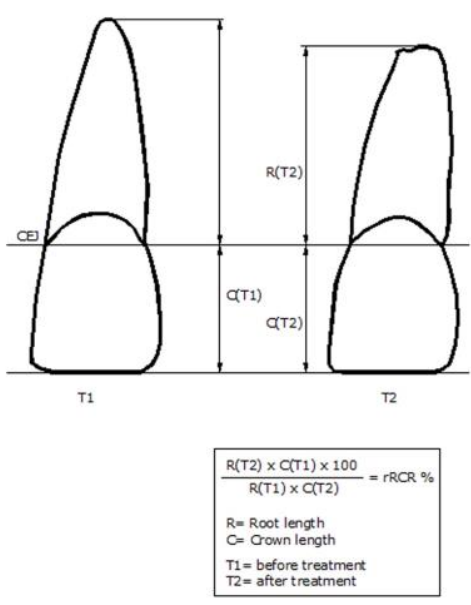

Figure 1. Measurement of the panoramic radiographs: root and crown lengths and the formula of the rRCR calculation in percentage; (CEJ=cemento-enamel junction).

rRCR was assessed according to Gay et al. ${ }^{22}$ as following:

rRCR $=100 \%$ : No change between the initial and final root length

$90 \% \leq$ rRCR $<100 \%$ : Mild resorption

$80 \% \leq$ rRCR $<90 \%$ : Moderate resorption

rRCR $\leq 80$ : Severe resorption
The measurements were made from printed digital panoramic and cephalometric radiographs. The measurements on the panoramic radiographs were made by an experienced radiologist with a digital caliper (CD-S15; Mitutoyo, Tokyo, Japan) using a view box under fourfold magnification with subdued lightning.

The amount and direction of the apical displacement of incisors were assessed on the pre-and post-treatment lateral cephalograms. The tracings of the cephalograms were superimposed to provide the best fit of anatomic structures. These were oriented to the palatal plane and ANS for the maxilla, and the mandibular plane and menton for the mandible by an experienced orthodontist (Figures 2 and 3).

Additionally, possible risk factors (age, gender, tooth type, Forsus FRD, and total treatment durations and apical displacement) were assessed.

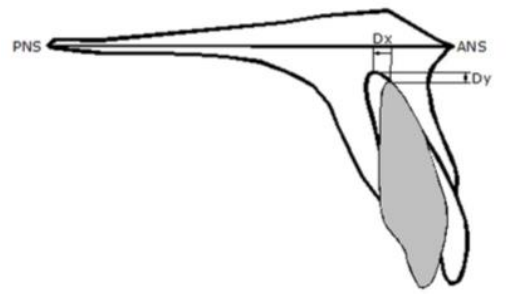

Figure 2. Analysis of the sagittal (Dx) and vertical (Dy) apical displacement of upper incisors using pre-and post-treatment lateral cephalograms.

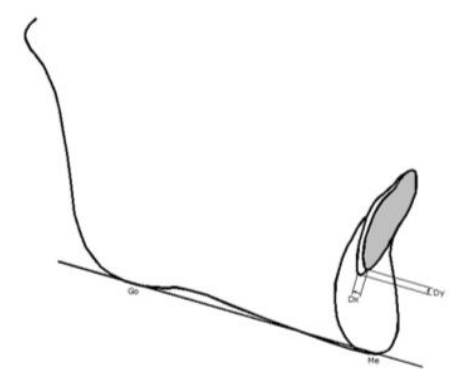

Figure 3. Analysis of the sagittal (Dx) and vertical (Dy) apical displacement of lower incisors using pre-and post-treatment lateral cephalograms.

\section{Statistical Analysis}

Statistical analysis was performed with SPSS statistical software package (SPSS Statistics for Windows, version 23. IBM Corp, Armonk, NY). Descriptive statistics were performed for the data. Pearson's correlation coefficient was used to investigate the significant relationships between rRCR and other variables (etc. age, sex). Radiographs of the

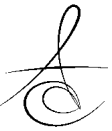


randomly selected 20 patients were measured again two weeks later to verify the reliability of the results. Intraclass correlation coefficients ranged from 0.952 to 0.984 presenting a high reproducibility and reliability between the first and second measurements.

\section{RESULTS}

ARR was observed in $66(90.41 \%)$ patients with a mean number of 3.46 teeth affected. Eleven patients $(15.07 \%)$ had a mean of 1.55 teeth affected with severe ARR $(r R C R<80 \%)$ and 14 patients (27.39\%) had a mean of 1.5 teeth affected with moderate ARR $(80 \leq r R C R<90)$ (Table 1$)$.

Table 1. Number ( $\mathrm{n}$ ) and percentage (\%) of patients in accordance with the severity of rRCR.

\begin{tabular}{|c|c|c|c|c|c|c|c|c|}
\hline \multirow[b]{2}{*}{ rRCR } & \multicolumn{6}{|c|}{$\begin{array}{c}\text { Patients with ARR } \\
\mathrm{n}\end{array}$} & \multirow[b]{2}{*}{$\begin{array}{c}\text { Teeth } \\
\text { n }\end{array}$} & \multirow{2}{*}{$\begin{array}{c}\text { Mean } \\
\text { teeth } \\
\text { per } \\
\text { patient } \\
\text { n }\end{array}$} \\
\hline & $\begin{array}{c}1 \\
\text { tooth }\end{array}$ & $\begin{array}{c}2 \\
\text { teeth }\end{array}$ & $\begin{array}{c}3 \\
\text { teeth }\end{array}$ & $\begin{array}{c}4 \\
\text { teeth }\end{array}$ & $\begin{array}{c}\geq 5 \\
\text { teeth }\end{array}$ & \begin{tabular}{|c|} 
total \\
patient \\
$(\%)$ \\
$(\%)$
\end{tabular} & & \\
\hline rRCR $<80$ & 7 & 2 & 2 & - & - & $11(15.07)$ & 17 & 1.55 \\
\hline $\begin{array}{l}80 \leq r R C R \\
<90\end{array}$ & 14 & 4 & - & 2 & - & $20(27.39)$ & 30 & 1.50 \\
\hline $\begin{array}{l}\text { Total rRCR } \\
<90\end{array}$ & 16 & 5 & - & 4 & 1 & $26(35.62)$ & 47 & 1.81 \\
\hline $\begin{array}{l}90 \leq \mathrm{rRCR} \\
<100\end{array}$ & 16 & 20 & 8 & 13 & 9 & $35(47.95)$ & 181 & 2.74 \\
\hline $\begin{array}{l}\text { Total rRCR } \\
<100\end{array}$ & 10 & 16 & 11 & 12 & 17 & $66(90.41)$ & 228 & 3.46 \\
\hline
\end{tabular}

ARR (rRCR<100\%) was detected in 228 (\%16.67) teeth. Mild ARR $(90 \leq r R C R<100 \%)$ was determined in $13.23 \%(n=181)$, and moderate ARR $(80 \leq r R C R<90 \%)$ was present in $2.19 \%(n=30)$ of the sample. Severe ARR ( $r R C R<80 \%)$ was observed in $1.24 \%(n=17)$ of all teeth (Table 2$)$.

Table 2. Number ( $\mathrm{n}$ ) and percentage (\%) of teeth in accordance with the severity of rRCR.

\begin{tabular}{|c|c|c|}
\hline \multirow{2}{*}{ rRCR\% } & \multicolumn{2}{|c|}{ Teeth } \\
\cline { 2 - 3 } & n & \% \\
\hline rRCR $<80 \%$ & 17 & 1.24 \\
\hline $80 \leq$ rRCR $<90$ & 30 & 2.19 \\
\hline $90 \leq$ rRCR $<100$ & 181 & 13.23 \\
\hline total rRCR $<100$ & 228 & 16.67 \\
\hline rRCR $\geq 100$ & 1140 & 83.33 \\
\hline Total & 1368 & 100 \\
\hline
\end{tabular}

The number and rRCR for each tooth in the maxillary and mandibular arches are demonstrated in Tables 3 and 4 respectively. The prevalence of severe ARR was greater in the upper central and lateral incisor teeth than the lower central incisors. Mild to moderate ARR was observed more frequently in the lower incisors and, ranged from $21.5 \%$ to $35.9 \%$.

Table 5 presents the correlation of risk factors with the extent and severity of ARR. Age and tooth type showed significant weak negative correlations with rRCR $(p<0.05)$. The extent/severity of ARR increased with advanced age. No significant relationship was found between the extent/severity of ARR and gender, Forsus FRD, or total treatment time ( $p>0.05)$.

Table 6 shows the directions and amount of apical displacement of the upper and lower central incisors and the correlation between apical displacement and rRCR. No significant relationship was found between the extent/direction of apical displacement and ARR in either maxillary or mandibular incisors $(p>0.05)$.

Table 3. Number $(\mathrm{n})$ and percentage (\%) of each tooth in accordance with severity of rRCR in the maxilla. Teeth are numbered according to the FDI system.

\begin{tabular}{|c|c|ccc|c|ccc|}
\hline rRCR\% & $\mathbf{1 1 ( n = 6 6 )}$ & $\mathbf{1 2}(\mathbf{n}=\mathbf{6 6})$ & $\mathbf{1 3 ( n = 6 9 )}$ & $\mathbf{1 5}(\mathbf{n}=\mathbf{7 2})$ & $\mathbf{2 1 ( n = 6 4 )}$ & $\mathbf{2 2 ( n = 6 5 )}$ & $\mathbf{2 3 ( n = 6 8 )}$ & $\mathbf{2 5 ( n = 6 9 )}$ \\
\hline no. of teeth & 2 & 1 & 0 & 0 & 4 & 3 & 0 & 0 \\
\hline rRCR $<80$ & $3 \%$ & $1.50 \%$ & $0 \%$ & $0 \%$ & $6.30 \%$ & $4.60 \%$ & $0 \%$ & $0 \%$ \\
no. of teeth & 0 & 1 & 2 & 0 & 2 & 1 & 1 & 1 \\
80? rRCR $<90$ & $0 \%$ & $1.50 \%$ & $2.90 \%$ & $0 \%$ & $3.10 \%$ & $6.20 \%$ & $1.50 \%$ & $1.40 \%$ \\
\hline no. of teeth & 6 & 7 & 8 & 5 & 9 & 5 & 5 & 6 \\
\hline 90? rRCR $<100$ & $9.10 \%$ & $10.60 \%$ & $11.60 \%$ & $6.90 \%$ & $14.10 \%$ & $13.80 \%$ & $7.40 \%$ & $8.70 \%$ \\
\hline no. of teeth & 8 & 9 & 10 & 5 & 15 & 9 & 6 & 7 \\
Total rRCR $<100$ & $12.12 \%$ & $13.63 \%$ & $14.49 \%$ & $6.94 \%$ & $23.43 \%$ & 13.84 & $8.82 \%$ & $10.14 \%$ \\
no. of teeth & 58 & 57 & 59 & 67 & 49 & 56 & 62 & 62 \\
\hline rRCR? 100 & $87.88 \%$ & $86.37 \%$ & $85.51 \%$ & $93.06 \%$ & $76.57 \%$ & $86.16 \%$ & $91.18 \%$ & $89.86 \%$ \\
\hline
\end{tabular}

Table 4. Number ( $n$ ) and percentage (\%) of each tooth presenting rRCR $=100 \%$ (no ARR), rRCR between 90 and 100 (mild ARR), rRCR between 80 and 90 (moderate ARR), and $\mathrm{rRCR}<80$ (severe ARR) in the mandibula. Teeth are numbered according to the FDI system.

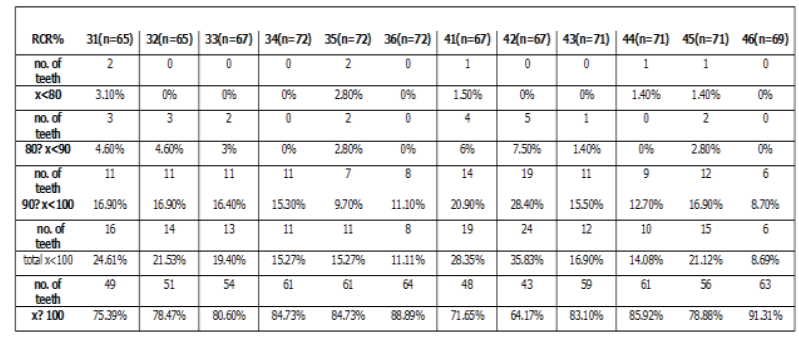

Table 5. Correlation between the extent/severity of rRCR with risk factors.

\begin{tabular}{|c|c|c|c|}
\hline & Correlation & & Correlation \\
\hline & & & \\
\hline Sex-rRCR & $-0.039(0.099)$ & Sex-rRCR (severity) & $-0.034(0.199)$ \\
\hline TTD-rRCR & $-0.018(0.373)$ & TTD-rRCR(severity) & $-0.027(0.234)$ \\
\hline FTD-rRCR & $0.018(0.437)$ & FTD-rRCR(severity) & $0.023(0.387)$ \\
\hline Age-rRCR & $-0.068(0.013)^{*}$ & \begin{tabular}{|l} 
Age-rRCR(severity) \\
\end{tabular} & $-0.190(0.048)^{*}$ \\
\hline $\begin{array}{l}\text { Tooth type- } \\
\text { rRCR }\end{array}$ & $-0.064(0.002)^{*}$ & $\begin{array}{l}\text { Tooth type- } \\
\text { rRCR(severity) }\end{array}$ & $-0.048(0.034)^{*}$ \\
\hline
\end{tabular}


Table 6. The mean values of apical displacements of upper and lower incisors and correlation between rRCR.

\begin{tabular}{|c|c|c|c|c|c|c|c|}
\hline \begin{tabular}{|l|} 
Upper incisor root \\
retrusion-rRRR
\end{tabular} & II & $\begin{array}{l}\text { Mean } \pm \text { SD } \\
2.38 \pm 1.54\end{array}$ & $\begin{array}{c}\text { Correlation } \\
\text { r p p } \\
0\end{array}$ & $\begin{array}{l}\text { Lower incisor root } \\
\text { retrusion-RCR }\end{array}$ & II & Mean \pm SD & $\begin{array}{c}\text { Correlation } \\
\mathbf{r} \quad \mathbf{p} \\
-0.051(0723)\end{array}$ \\
\hline protus son-PRCR & 20 & $2.11 \pm 1.41$ & $0.133(0.451)$ & prottusion-RRR & 30 & $1.57 \pm 0.64$ & $0.152(0.307)$ \\
\hline intrusion-rRCR & 12 & $1.09 \pm 0.49$ & $-0.073(0.782)$ & intrusion-rRCR & 22 & $1.54 \pm 1.00$ & $0.163(0.353)$ \\
\hline extrusion-rRCR & 41 & $1.78 \pm 1.06$ & $0.069(0.561)$ & extrusion-rRCR & 38 & $1.94 \pm 1.27$ & $-0.031(0.806)$ \\
\hline
\end{tabular}

\section{DISCUSSION}

Cephalometric, periapical, and panoramic radiographs are used for radiographic examination of orthodontic patients. ${ }^{23}$ Standardized periapical radiographs taken at the beginning and the end of the study could have been considered, however due to retrospective study design panoramic radiographs were used to assess ARR. It was stated that metric measurements on panoramic radiographs taken in constant angulation; with occlusal plane tilted no more than $10^{\circ}$, at different durations were satisfactory to estimate apical root changes. ${ }^{24}$ As previous studies, ${ }^{20-}$ ${ }^{22}$ we used the rRCR method to assess ARR since the ratio of crown-root length is considered to be constant between different panoramic radiographs. ${ }^{20}$

The upper molars and the first premolars couldn't be evaluated since the roots of these teeth are generally superimposed on panoramic radiographs. More detailed and accurate measurements could be obtained with three-dimensional imaging. However, in a recent meta-analysis study, it was reported that less than $1 \mathrm{~mm}$ of root resorption was determined on the average tooth after fixed orthodontic treatment with CBCT. Although a higher rate of root resorption was detected with CBCT compared to $2 \mathrm{D}$ imaging methods, there was little clinical compatibility causing the profits of $\mathrm{CBCT}$ questionable due to higher radiation dose. ${ }^{13}$

ARR was determined in $90 \%$ of the patients with an average number of 3.5 teeth at the end of treatment. Studies concerning Class II treatment reported a prevalence of ARR between $65.6 \%$ and $98.1 \%$ per patient. ${ }^{25,26}$ Moderate to severe ARR was detected in 26 cases $(35.61 \%)$ and severe ARR was determined in 11 cases (15\%). Results regarding severe ARR are similar to the findings of Eisel et al. ${ }^{27}$ who evaluated ARR in Class II treatment. This result supports the consensus that pronounced ARR is not a common problem following orthodontic treatment and individual disposition is a considerable factor. ${ }^{14}$
In the present study, 228 teeth (16.67\%) demonstrated some degree of ARR. When considering the severity of ARR, $2.19 \%$ of all teeth showed moderate resorptions and only $1.24 \%$ demonstrated severe ARR. Mild or moderate resorption is clinically acceptable. Also, mild ARR could be repaired by secondary cementum when orthodontic movement interrupts. ${ }^{28}$ However $3 \mathrm{~mm}$ of ARR (severe) leads to 1 $\mathrm{mm}$ periodontal ligament loss at the alveolar margin, which is a serious outcome. ${ }^{29}$ Therefore, it is very important to determine the potential risk factors for ARR.

In the systematic review of Tieu et al. ${ }^{17}$ it was concluded that severe ARR in terms of affected teeth in extraction/non-extraction treatment of Class II malocclusions was concordant with other orthodontic treatment studies in general.

Previous studies searching the prevalence of ARR in Class II Div 1 correction with other orthodontic mechanics $25-27,30-33$ generally reported mild to moderate ARR. This was higher than our results and may be due to the difference in evaluated teeth (only incisors in those studies), mechanics, and variability in study design.

Present findings revealed that severe ARR was detected more frequently in the upper central and lateral incisors, followed by the lower central incisors. The majority of previous studies have mostly investigated the ARR of maxillary incisors. These teeth are more prone to $A R R^{8,9}$ which may be attributed to apical displacement against the cortical plate and also bottle or blunted root shape. ${ }^{8}$

In this study, the incidence of moderate to severe ARR ranged from $3 \%$ to $10.8 \%$ in the maxillary incisors and from $4.6 \%$ to $7.7 \%$ in mandibular incisors. These findings are similar to the results of Martins et al. ${ }^{33}$ who corrected Class II Div 1 malocclusion with four first premolar extraction using headgear and/or class II elastics. Brin et al. ${ }^{34}$ reported that $11 \%$ of central and $14 \%$ of lateral incisor teeth (total 532 upper incisors) demonstrated moderate to severe ARR following Class II treatment. Taner et al..$^{30}$ found greater ARR in Class 2 II Div 1 treated cases ( $2 \mathrm{~mm})$ compared to Class I $(1 \mathrm{~mm})$ in upper central incisors.

In a recent meta-analysis study, it has been reported that mandibular anterior teeth following maxillary central and lateral incisors were frequently affected by ARR. ${ }^{35}$ We proposed that more frequent and severe ARR could occur especially in lower 
anterior teeth as Forsus FRD is directly applied to the distal side of the lower canines causing unfavorable labial tipping of the incisors. Present findings revealed that the severity of ARR detected in the lower incisors was mostly mild and moderate. The incidence of mild and moderate ARR in the mandibular incisors ranged from $4.6 \%$ to $7.5 \%$ and from $16.9 \%$ to $28.4 \%$, respectively. Mild ARR was mostly seen in the lower canines. Only a small number of mandibular anterior teeth were affected by severe resorption. Most studies regarding Class II treatment focused on maxillary incisors because it is generally difficult to evaluate the lower incisors on panoramic radiographs. However, we selected high-quality images therefore, we were able to evaluate the mandibular incisors. Meriç et al. ${ }^{36}$ assessed ARR in mandibular incisor teeth after treatment with Forsus FRD EZ2 and Bionator appliance with $\mathrm{CBCT}$. They found that the percentage of root volume loss was not significant for the mandibular incisors, except for the mandibular right second incisor in the Forsus FRD EZ2 group. Besides, they reported non-significant root volume loss in the Bionator group. Rekhawt et al. ${ }^{37}$ evaluated ARR with CBCT in patients treated with the Forsus appliance and found a significant reduction in root length in the central incisors and canines at the end of the treatment.

The amount and direction of the apical displacement of the incisors in the sagittal and vertical plane were assessed on the pre-and post-treatment lateral cephalograms. The tracings of the cephalograms were superimposed to provide the best fit of anatomic structures, oriented to the palatal plane and ANS for the maxilla, and mandibular plane and menton for the mandible. One should keep in mind that the Menton point that may change with growth and cause limitation of the measurement method related to the apical displacement of incisors. Thus, this may affect the vertical displacement of teeth, especially those with ARR. The amount and direction of apical displacement were claimed to be related to ARR. ${ }^{12,15,17}$ However, no considerable correlation was detected between the direction/extent of apical displacement and ARR in either maxillary or mandibular incisors in the present study. This result agrees with some studies. ${ }^{21,31,33}$ Contrary, vertical apical displacement was found as a crucial factor for ARR in both upper and lower incisors, whereas sagittal displacement was significantly correlated with ARR in the lower incisor teeth. ${ }^{15}$
Regarding influence factors, there was no significant relationship between severity of resorption and parameters such as gender, Forsus FRD, or total treatment time which is consistent with the results of other studies ${ }^{6,20,21,25}$ The contrary, some authors reported that the amount of root shortening increased with longer treatment time. ${ }^{11-13,25,32,34}$

The reasons for the non-significant relationship between treatment time and ARR may be explained with sample size, root form, initial root length, the distance of root apexes to cortical plates, the amount of movement of the roots, and initial malocclusion type. ${ }^{6}$ The Forsus FRD and full fixed technique may not have produced a longtime high pressure on teeth. Also, we used 2D radiographs. Due to the superimposition of peripheral anatomical structures on teeth roots, ARR located in buccal, palatal/lingual, mesial, or distal surfaces, may not be visible in 2D radiography. Also, resorption cavities may progress into the root dentine without any reduction in the root length in longer orthodontic treatment time and orthodontic forces. ${ }^{38}$

In this study, ARR was significantly higher in older patients in accordance with Mavragani et al.'s $\mathrm{s}^{31}$ findings. Additionally, the tooth category correlated significantly with ARR indicating more prevalent and severe resorption in anterior teeth in accordance with Samandra et $\mathrm{al}^{\prime} \mathrm{s}^{13}$ findings. In contrast, Krieger et al. ${ }^{21}$ didn't find any significant correlation between rRCR and tooth type or age.

\section{CONCLUSION}

Ninety percent of the cases exhibited ARR with a mean of 3.5 teeth affected. ARR of the incisors appeared to be more prevalent than other teeth in both arches. Severe ARR was confined to only a few cases and was detected more frequently in the upper central and the lateral incisors, followed by the lower central incisors. ARR in the lower incisors generally ranged from mild to moderate. ARR in the anchorage lower canine teeth were mostly mild. Age and tooth types were determined as risk factors for ARR whereas gender, treatment duration or direction, and amount of apical displacement were not found as risky. 


\section{Acknowledgement}

We would like to thank Idea Tercüme (www.ideatercume.com) for English language translation.

\section{DECLARATIONS}

Ethics approval and consent to participate

Ethical approval for this retrospective study was granted by Gazi University Ethics Committee (Approval number: 2018-227).

\section{REFERENCES}

1.Kolcuoğlu K, Oz AZ. Comparison of orthodontic root resorption of root-filled and vital teeth using microcomputed tomography. Angle Orthod 2020;90:5662.

2.Yıldırım M, Akın M. Comparison of root resorption after bone-borne and tooth-borne rapid maxillary expansion evaluated with the use of microtomography. Am J Orthod Dentofacial Orthop 2019;155:182-90.

3.Pamukçu H, Polat-Özsoy Ö, Gülşahi A, Özemre MÖ. External apical root resorption after nonextraction orthodontic treatment with labial vs. lingual fixed appliances. J Orofac Orthop 2020;81:41-51.

4. Lund H, Gröndahl K, Hansen K, Gröndahl HG. Apical root resorption during orthodontic treatment. A prospective study using cone beam CT. Angle Orthod 2012;82:480-7.

5. Linge $\mathrm{L}$, Linge $\mathrm{BO}$. Patient characteristics and treatment variables associated with apical root resorption during orthodontic treatment. Am J Orthod 1991;99:35-43.

6. Mirabella AD, Artun J. Risk factors for apical root resorption of maxillary anterior teeth in adult orthodontic patients. Am J Orthod 1995;108:4855.

7. Blake M, Woodside DG, Pharoah MJ. A radiographic comparison of apical root resorption after orthodontic treatment with the edgewise and speed appliances. Am J Orthod 1995;108:76-84.

8. Weltman B, Vig KW, Fields HW, Shanker S, Kaizar EE. Root resorption associated with orthodontic tooth movement: a systematic review. Am J Orthod Dentofac Orthop 2010;137:462-76.

9. Sameshima GT, Sinclair PM. Predicting and preventing root resorption: Part I. Diagnostic factors. Am J Orthod Dentofacial Orthop 2001; 119: 505-10.

10. Kaley J, PhillipsC. Factors related to root resorption in edgewise practice. Angle Orthod 1991; 61:125-32.
11. Maués $C P$, do Nascimento RR, Vilella Ode V. Severe root resorption resulting from orthodontic treatment: prevalence and risk factors. Dental Press J Orthod 2015;20:52-8.

12. Fox N. Longer orthodontic treatment may result in greater external apical root resorption. Evid Based Dent 2005;6:21.

13. Samandara A, Papageorgiou SN, IoannidouMarathiotou I, Kavvadia-Tsatala S, Papadopoulos MA.Evaluation of orthodontically induced external root resorption following orthodontic treatment using cone beam computed tomography (CBCT): a systematic review and meta-analysis. Eur J Orthod 2019; 23;41:67-79.

14. Lupi JE, Handelman CS, Sadowsky C. Prevalence and severity of apical root resorption and alveolar bone loss in orthodontically treated adults. Am J Orthod Dentofacial Orthop 1996;109:28-37.

15. Kim KW, Kim SJ, Lee JY, Choi YJ, Chung CJ, Lim $\mathrm{H}$, Kim KH. Apical root displacement is a critical risk factor for apical root resorption after orthodontic treatment. Angle Orthod 2018; 88:740-747.

16. Darendeliler M A, Kharbanda O P, Chan E K M, Srivicharnkul P, Rex T, Swain M V, Jones A S, Petocz $P$. Root resorption and its association with physical properties of, mineral contents and resorption craters in human premolars following application of light and heavy forces. Orthod Craniofac Res 2004;7:79-97.

17. Tieu LD, Saltaji H, Normando D, Flores-Mir C. Radiologically determined orthodontically induced external apical root resorption in incisors afternonsurgicalorthodontictreatment of class II division 1 malocclusion: a systematic review. Prog Orthod 2014;15:48.

18. Kinzinger GS, Savvaidis S, Gross U, Gülden N, Ludwig B, Lisson J. Effects of Class II treatment with a banded Herbst appliance on root lengths in the posterior dentition. Am J Orthod Dentofacial Orthop 2011;139:465-469.

19. Linjawi AI, Abbassy MA. Dentoskeletal effects of the forsus ${ }^{\mathrm{TM}}$ fatigue resistance device in the treatment of class II malocclusion: Asystematic review and meta-analysis. J Orthod Sci 2018;7:5.

20. Fritz $U$, Diedrich $P$, Wiechmann D. Apical root resorption after lingual orthodontic therapy. J Orofac Orthop 2003;64:434-42.

21.Krieger E, Drechsler T, Schmidtmann I, Jacobs C, Haag S, Wehrbein H. Apical root resorption during

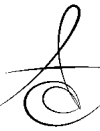


orthodontic treatment with aligners? A retrospective radiometric study. Head Face Med 2013;9:21.

22.Gay G, Ravera S, Castroflorio T, Garino F, Rossini G, Parrini S, Cugliari G, Deregibus A. Root resorption during orthodontic treatment with Invisalign: a radiometric study. Prog Orthod 2017;18:12.

23.Alver A. Erişkinlerde ortodontik tanı ve tedavi. Atatürk Üniv Diş Hek Fak Derg 1997;7:92-101.

24.Stramotas S, Geenty JP, Petocz P, Darendeliler MA. Accuracy of linear and angular measurements on panoramic radiographs taken at various positions in vitro. Eur J Orthod 2002;24:43-52

25.DeShields RW. A study of root resorption in treated Class II Division I malocclusions. Angle Orthod 1969;39:231-45.

26.Reukers E, Sanderink G, Kuijpers-Jagtman A, van't Hof M. Radiographic evaluation of apical root resorption with 2 different types of edgewise appliances. Results of a randomized clinical trial. ] Orofac Orthop 1998;59:100-9.

27. Eisel A, Katsaros C, Berg R. The course and results of the orthodontic treatment of 44 consecutively treated Class-II cases. Fortschr Kieferorthop 1994;55:1-8.

28. Estrela C, Bueno MR, De Alencar AH, Mattar R, Valladares Neto J, Azevedo BC, De Araújo Estrela CR. Method to evaluate inammatory root resorption by using cone beam computed tomography. J Endod 2009;35:1491-7.

29.Kalkwarf LL, Kreyci RF, Pao YC. Effect of apical root resorption on periodontal support. J Prosthet Dent 1986;56:317-9.

30.Taner T, Ciger S, Sencift Y. Evaluation of apical root resorption following extraction therapy in subjects with Class I and Class II malocclusions. Eur J Orthod 1999;21:491-6.

31.Mavragani $M$, Boe OE, Wisth $P J$, Selvig KA. Changes in root length during orthodontic treatment: advantages for immature teeth. Eur J Orthod 2002;24:91-7.

32.Liou EJW, Chang PMH. Apical root resorption in orthodontic patients with en-masse maxillary anterior retraction and intrusion with miniscrews. Am J Orthod Dentofacial Orthop 2010;137:207-12.

33. Martins DR, Tibola D, Janson G, Maria FRT. Effects of intrusion combined with anterior retraction on apical root resorption. Eur J Orthod 2012;34:1705.
34.Brin I, Tulloch JF, Koroluk L, Philips C. External apical root resorption in Class II malocclusion: a retrospective review of 1-versus 2-phase treatment. Am J Orthod Dentofacial Orthop 2003;124:151-6.

35.Deng $Y$, Sun $Y, X u$ T. Evaluation of root resorption after comprehensive orthodontic treatment using cone beam computed tomography(CBCT): a metaanalysis. BMC Oral Health 2018;18:116.

36. Meriç $\mathrm{P}$, Bilgiç Zortuk F, Karadede Mİ. Volumetric measurements of mandibular incisor root resorption following Forsus FRD EZ2 and Bionator appliance treatment using cone-beam computed tomography: A preliminary study. APOS Trends Orthod 2020;10:96-104.

37.Rekhawat A, Durgekar SG, Reddy S. Evaluation of root resorption, tooth inclination and changes in supporting bone in class II malocclusion patients treated with Forsus appliance. Turk J Orthod 2020;33:21-30.

38.Casa MA, Faltin RM, Faltin K, Sander FG, AranaChavez VE. Root resorptions in upper first premolars after application of continuous torque moment. Intra-individual study. J Orofac Orthop 2001;62:285-95.

\section{Sorumlu Yazarın Yazışma Adresi}

Dr. Zühre Akarslan, Professor, Department of Oral and Maxillofacial Radiology, University of Gazi, 06510 Emek, Ankara, Türkiye

Tel: 03122872629

E-mail: dtzuhre@yahoo.com 